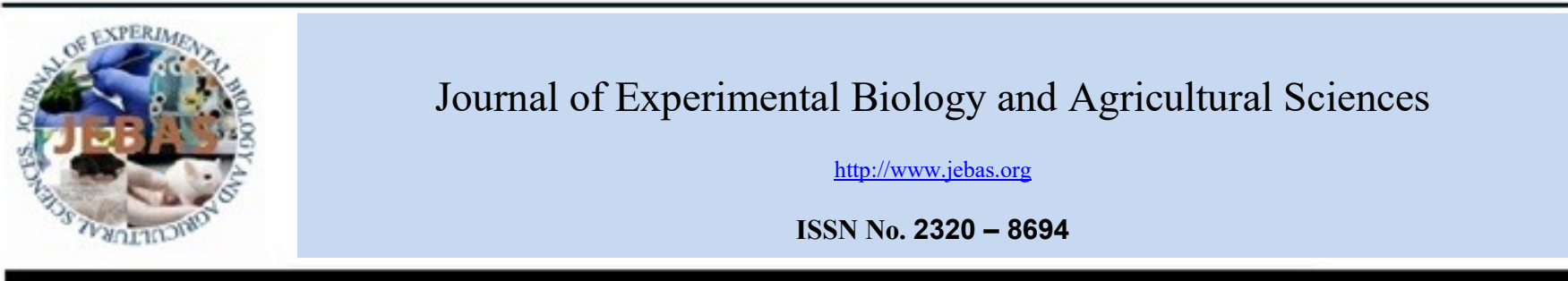

\title{
GENETIC ANALYSIS OF GREEN GARDEN LOOPER, Chrysodeixis eriosoma (LEPIDOPTERA: NOCTUIDAE: PLUSIINAE) USING MITOCHONDRIAL COI GENE SEQUENCES FROM INDIA
}

\author{
Twinkle ${ }^{1,2}$, Shashank $\mathrm{PR}^{1 *}$, Pratima Chaudhuri Chattopadhyay ${ }^{2}$ \\ ${ }^{1}$ National Pusa Collection, Division of Entomology, ICAR-Indian Agricultural Research Institute, New Delhi-110012, India \\ ${ }^{2}$ Amity Institute of Biotechnology, Amity University, Noida, Uttar Pradesh-201303, India \\ Received - May 23, 2020; Revision - June 07, 2020; Accepted - June 22, 2020 \\ Available Online - June 25, 2020 \\ DOI: http://dx.doi.org/10.18006/2020.8(3).269.275 \\ KEYWORDS \\ Chrysodeixis eriosoma \\ Pest \\ Genetic diversity \\ Phylogeny \\ India

\begin{abstract}
Green garden looper, Chrysodeixis eriosoma, has emerged as one of the major insect pests of agronomic and vegetable crops causing considerable crop losses. In the present study, samples from eleven different localities of India were used for the investigation of genetic diversity of $C$. eriosoma by employing a fragment in the mtDNA gene-encoding cytochrome oxidase I (COI). Based on the partial COI gene, less nucleotide diversity $(\pi=0.00314)$ among Indian and global C. eriosoma populations were observed, whereas nucleotide diversity within Indian populations is nonsignificant $(\pi=0.00079)$. Additionally, phylogenetic analysis of COI sequences grouped all the Indian and global populations into one cluster. This is the first attempt for diversity assessment of C. eriosoma populations from India.
\end{abstract}

* Corresponding author

E-mail: spathour@gmail.com (Shashank PR)

Peer review under responsibility of Journal of Experimental Biology and Agricultural Sciences.

Production and Hosting by Horizon Publisher India [HPI] (http://www.horizonpublisherindia.in/).

All rights reserved.
All the articles published by Journal of Experimental Biology and Agricultural Sciences are licensed under a Creative Commons Attribution-NonCommercial 4.0 International License Based on a work at www.jebas.org.

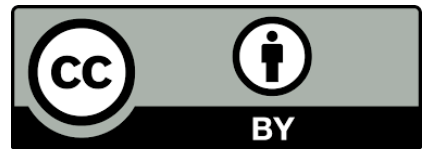




\section{Introduction}

Insects are a diverse group of organisms and can use a wide range of plant species as hosts (Despres et al., 2007). Noctuidae is the second largest family in Noctuoidea, with about 1,089 genera and 11,772 species (Zhang, 2011). Plusiinae is the type subfamily of Noctuidae, has a cosmopolitan range distribution and comprises 500 species in four tribes and 36 genera worldwide (Ronkay et al. 2008). Morphologically Plusiinae are dark-colored moths having a similar general appearance with brighter silver gamma mark/golden patch on their forewing. It includes approximately 59 described species (Shashank \& Longjam, 2014) including many widely distributed pests for various agronomic and vegetable crops of India (Twinkle et al., 2018). Chrysodeixis eriosoma (Doubleday, 1843), a member of this subfamily, commonly known as green garden looper is a worldwide serious polyphagous pest. It found throughout Asia, Europe, North, and South America and Oceania. It is also recorded from Australia, Fiji, New Zealand, Papua New Guinea and Tonga (Ronkay et al., 2010). In India, it is reported from Assam, Delhi, Maharastra, Tamil Nadu, Uttar Pradesh, Uttarakhand, Arunachal Pradesh, Himachal Pradesh, Kerala, Rajasthan and Meghalaya (Shashank \& Singh, 2014). The green garden looper, C. eriosoma (Lepidoptera: Noctuidae), is one of the major constraints hampering productivity in crops globally. The larva of this species are predominantly feeding on the plants of families Solanaceae (Broza \& Sneh, 1994; EPPO, 2004), Asteraceae (Compositae), Brassicaceae (Hill, 1983; Anonymous, 1984), Cucurbitaceae, Fabaceae, Poaceae including economical crops like tomato, beans, pumpkin, capsicum, tobacco (Martin \& Workman 1986; Tripathi \& Shari, 1992). The early instar larvae of this species feeds by rolling of leaf and webbing (CABI, 2007), while later instars voracious feeders and feed entire leaf leaving midrib and other large veins (Taylor \& Kunjecku, 1983). The pest species was recorded first time from a pea plant in Delhi by Prasad et al., 1983. Further, in India, Pea, Soybean, Cabbage, Potato, Berseem, Cauliflower, Chickpea, Sunflower and Lentils are known to be most preferred hosts of C. eriosoma (Prasad et al.,1983; Saha \& Saharia, 1983; Butani \& Jotwani, 1984; Tripathi \& Akhtar, 1986; Tripathi \& Tripathi, 1988; Tripathi \& Akhtar, 1988; Men et al., 1995; Sharma et al., 2008; Nair et al., 2017). Fecundity table and intrinsic rate of natural increase in C. eriosoma (Doubleday) was studied by Tripathi \& Shari 1992. The genus Chrysodeixis comprises five species which were found in India, viz. C. eriosoma, $C$. chalcites (Esper, 1789), C. acuta (Walker, 1858 ), C. minutus (Dufay , 1970) and C. permissa (Walker, 1858). However, C. eriosoma, C. chalcites, C. acuta considered as sibling species and all are considered as a serious crop pest. These pest species usually identified by its morphological and genitalial variation within species but always confusing because of identical structures of genitalia with very little variation. So, proper identification of these species by various molecular analysis tools is very important for proper pest management. The aim of this study is to describe the basic information for molecular variability and population genetic structure of C. eriosoma using mitochondrial marker cytochrome C oxidase (COI). This study particularly focused upon the DNA barcode gene, which has been found to be a promising method and is being used to identify species, subspecies, cryptic species of insect pest.

\section{Materials and Methods}

\subsection{Sampling}

Moth specimens were collected from eight different states i.e. Arunachal Pradesh, Delhi, Kerala, Himachal Pradesh, Uttarakhand, Rajasthan, Punjab, and Meghalaya and eleven different localities of India. The light traps method was used for the collection of adult moths. Further, collected specimens were processed by pinning, spreading, proper labeling, and preparation of wings and genitalia slides. All the specimens are preserved in NPC-IARI, New Delhi.

\subsection{Morphology}

Male and female specimens were identified morphologically by using a stereomicroscope. Genital characters are predominantly used for discriminating species of C. eriosoma and afford better diagnostic value than external wing patterns or coloration. More than 20 specimens were dissected to examine cases where there was a conflict between morphology-based identification and the DNA barcode results.

\subsection{DNA extraction, COI amplification, and sequencing}

The DNA was extracted from the individual of C. eriosoma using DNeasy Blood and Tissue Kit (Qiagen GmbH, Germany) following the manufacture's protocol. The forward LCO-5'-GGT CAA CAA ATC ATA AAG ATA TTG G-3', and reverse HCO-5'-TAA ACT TCA GGG TGA CCA AAA AAT CA-3' primers specific to COI were applied in this study (Folmer et al. 1994). PCR amplification was performed on a BioRad thermal cycler with the following conditions: initial denaturation for $5 \mathrm{~min}$ at $94^{\circ} \mathrm{C}$ followed by 35 cycles of denaturing for $30 \mathrm{~s}$ at $94^{\circ} \mathrm{C}$, annealing for $40 \mathrm{~s}$ at $47^{\circ} \mathrm{C}$ and an extension time of $40 \mathrm{~s}$ at $72^{\circ} \mathrm{C}$, with a final extension for $5 \mathrm{~min}$ at $72^{\circ} \mathrm{C}$. The optimized PCR conditions (per $25 \mu \mathrm{L}$ ) using $0.1 \mu \mathrm{L}$ Dream Taq DNA polymerase $(5 \mathrm{U} / \mu \mathrm{L}), 2.5 \mu \mathrm{L}$ of $10 \mathrm{X}$ PCR buffer with $2 \mu \mathrm{L}$ of $25 \mathrm{mM} \mathrm{MgCl} 2,0.5 \mu \mathrm{L}$ of $10 \mathrm{mM}$ dNTPs, $0.5 \mu \mathrm{L}$ each of forward and reverse primers, $16 \mu \mathrm{L}$ of nuclease-free water. Each PCR reaction mixture contained $2.0 \mathrm{ml}$ of DNA template. The resultant PCR products were identified and sized by electrophoresis in a $1 \%$ TAE-agarose gel with 100 bp DNA ladder. Bands were visualized by ethidium bromide staining and samples yielded fragments of the expected size of $700 \mathrm{bp}$. Single bands were purified using a QIAquick PCR purification kit (Qiagen GmbH, Germany). Purified PCR products were sequenced directly in both directions using an automated sequencer (ABI prism ${ }^{\circledR} 3730$ XL DNA Analyzer; Applied Biosystems, USA) at Scigenomics Lab, Cochin, 
India. Authenticity of COI sequences obtained from this study was cross-checked with reference sequences of database. The sequence details were analyzed carefully and submitted to NCBI for the GenBank Accessions number (Table 1).

\subsection{Data analysis}

Nucleotide sequences for the isolates were compared with data deposited previously in GenBank using BLAST (http://blast.ncbi.nlm.nih.gov/Blast.cgi). Clustal W was used for multiple sequence alignment. Relationships among samples were then visualized by constructing a tree using the Maximum-likelihood method with 1000 bootstrap replicates based on p-distances. Following the removal of duplicate identical sequences from single locations, the analysis included 37 nucleotide sequences.
Evolutionary analyses were performed in MEGA6 (Tamura et al., 2013). The CO1 sequences newly obtained in this study were submitted to GenBank under Accession Nos. MN036462, MK861930, MK861931, MN036477, MN036467, MK861928, MK861929, MN036475, MN036478, MK861924, MK861925, MK861926, MK861927, MN036505, MN036466, MN036519, MK000724, MK840846, MK840845, MK861922, MK861923 and MF140488. These were combined with sequence data downloaded from GenBank for other country populations. Two sequences of Spodoptera exigua was used as an out group in the analysis. A total of 37 sequences ( 22 from this study and 15 sequences from different countries were downloaded from NCBI database) were used in diversity analysis. DnaSP 5.10.01 (Librado \& Rozas, 2009) was used to estimate a series of population-level parameters including pairwise nucleotide diversity $\pi$ and haplotype diversity $h$. Neutrality tests like

Table 1 Details of the sample data used in the analyses of C. eriosoma population

\begin{tabular}{|c|c|c|c|c|}
\hline countries & Accession no./BOLD sample Id. & Specific location & Latitude & Longitude \\
\hline \multicolumn{5}{|l|}{ India } \\
\hline Arunachal Pradesh & MN036462, MK861930, MK861931 & Khonsa & 26.995 & 95.497 \\
\hline Delhi & $\begin{array}{l}\text { MN036477, MN036467, } \\
\text { MK861928, MK861929 }\end{array}$ & IARI Campus & 28.632 & 77.165 \\
\hline Kerala & MN036475 & Pandimotta & 8.827 & 77.216 \\
\hline Himachal Pradesh & MN036478 & Nauni & 30.856 & 77.164 \\
\hline Himachal Pradesh & MK861924, MK861925 & Katrain & 32.097 & 77.135 \\
\hline Himachal Pradesh & MK861926, MK861927 & Dalang & 32.508 & 77.006 \\
\hline Uttarakhand & MN036505, MN036466 & Dehradun & 30.344 & 77.998 \\
\hline Rajasthan & MN036519, MK000724 & Durgapura & 25.495 & 78.557 \\
\hline Punjab & MK840846, MK840845 & Patiala & 30.356 & 76.453 \\
\hline Punjab & MK861922, MK861923 & Ludhiana & 30.902 & 75.808 \\
\hline Meghalaya & MF140488 & Umiam & 25.676 & 91.843 \\
\hline USA & KM870778.1 & Hawaii & \multirow[b]{2}{*}{-} & \multirow[b]{2}{*}{-} \\
\hline USA & CNCLEP00083727 & Hawaii & & \\
\hline Pakistan & HQ991371.1 & Malamjabba & \multirow[b]{2}{*}{-} & \multirow{2}{*}{-} \\
\hline Pakistan & HQ991185.1 & Malamjabba & & \\
\hline Papua New Guinea Papua & KP850853.1 & Morobe & \multirow[b]{2}{*}{-} & \multirow[b]{2}{*}{-} \\
\hline New Guinea & USNM ENT 00209666 & Madang & & \\
\hline Canada & KX860528.1 & - & - & - \\
\hline Malaysia & BIOUG21481-C10 & - & - & - \\
\hline \multirow{2}{*}{$\begin{array}{l}\text { French Polynesia } \\
\text { French Polynesia }\end{array}$} & CCDB-34794-A10 & Marquesas Islands & \multirow{2}{*}{ - } & \multirow{2}{*}{-} \\
\hline & USNM ENT 01068037 & Marquesas Islands & & \\
\hline \multirow{2}{*}{$\begin{array}{l}\text { Australia } \\
\text { Australia }\end{array}$} & ANIC.000788 & Queensland & \multirow{2}{*}{-} & \multirow{2}{*}{ - } \\
\hline & 10ANIC.08304 & Queensland & & \\
\hline \multirow{2}{*}{$\begin{array}{l}\text { China } \\
\text { China }\end{array}$} & \multirow{2}{*}{ NHMO-DAR-10552 ARB00009625 } & Nantong & \multirow{2}{*}{ - } & \multirow{2}{*}{-} \\
\hline & & Yunnan & & \\
\hline Seychelles & USNM ENT 01068096 & Aldabra Atoll & - & - \\
\hline \multicolumn{5}{|l|}{ Outgroups } \\
\hline spodoptera exigua & ABOLA884-15 & India & - & - \\
\hline spodoptera exigua & BBLOC1615-11 & India & & \\
\hline
\end{tabular}

Journal of Experimental Biology and Agricultural Sciences

http://www.jebas.org 
Table 2 Genetic variability of COI sequences

\begin{tabular}{|cccc|}
\hline & Rest of the world & India & Total \\
\hline Sample size & 15 & 22 & 37 \\
\hline No. of haplotypes $(\mathrm{h})$ & 4 & 2 & 0.704 \\
\hline Haplotype diversity $(\mathrm{Hd})$ & 0.638 & 0.091 & 0.00314 \\
\hline Nucleotide diversity $(\pi)$ & 0.00348 & 0.00079 & 15 \\
\hline No. of segregating sites $(S)$ & 11 & 5 & $-3.62503(* *, \mathrm{P}<0.02)$ \\
\hline Fu and Li's $F$ & -2.66343 & -3.06643 & $-3.63130(* *, \mathrm{P}<0.02)$ \\
\hline Fu and Li's $D$ & -2.53453 & -2.91519 & $-1.92787(*, \mathrm{P}<0.05)$ \\
\hline Tajima's $D$ & -1.74928 & -1.98725 & -0.045 \\
\hline Fu's $F$ & 1.103 & 1.274 & 0.10 \\
\hline
\end{tabular}

Fu and Li's $F$ and $D$ and Tajima's $D$ values, significant $(P<0.05)$ values, while others have $P>0.10$

Tajima's $D$ (Tajima, 1989), Fu and Li's $D$ (Fu \& Li, 1993), and Fu's FS (Fu, 1997), were also calculated by DnaSP 5.10.01 (Librado \& Rozas 2009) for investigating the historical population demographics and testing whether the sequences conformed to the expectations of neutrality.

\section{Results}

\subsection{Genetic diversity of $C$. eriosoma based on COI sequence data}

Twenty-two individuals of C. eriosoma were collected from eleven different localities of India. Other 15 sequences were downloaded from the NCBI database from nine countries based on the spread of C. eriosoma (Table 1). The sample size disparity is mainly based on the lack of sequence information from different countries. 37 sequences were used for analysis. The mean total nucleotide composition is A $29.8 \%$, T $40.1 \%$, C $15.5 \%$, and $\mathrm{G} 14.6 \%$ in the sequences. The average AT content is $69.9 \%$ and the $\mathrm{CG}$ is $30.1 \%$. This high AT content $(69.9 \%)$ is a general feature of the COI region in arthropods and is comparable with other studies on insect and mite taxa. Furthermore, test statistics were generated for the 37 $\mathrm{COI}$ sequences in which the rest of the world group and India were analyzed as discrete units in the case of the diversity and selective neutrality tests (Table 2). Surprisingly, there is a lack of variation in $C O I$ sequences. A total four haplotypes in the rest of the world group and two haplotypes in India were observed. There is negligible nucleotide diversity $(\pi) 0.00314$ among the total world population of C.eriosoma (Table 2). Demographic history changes were analyzed for two groups through neutrality tests.

\subsection{Phylogenetic analysis}

The Maximum-likelihood tree (ML tree based on Kimura threeparameter distance at 2000 iterations) was constructed based on 37 sequences including 22 sequences from the present study and 15 sequences from GenBank and outliers (Table 1) using MEGA 6.0. Based on the strict consensus ML tree, all populations cluster together in a single group. The phylogenetic tree had a total branch length of 0.14211 base substitutions per site. The tree shows that there is no clustering associated with geographic origin. However, the samples from the different localities are grouped with Indian samples as a base. This suggests that there is a homogeneity in the C. eriosoma populations.

\section{Discussion and conclusions}

Results from the present study have confirmed that C. eriosoma populations across different countries are genetically homogeneous. However, based on coxl analysis, high genetic homogeneity among different populations is evident by less nucleotide variation. Furthermore, the lack of genetic variability was also represented by Maximum-likelihood tree (Figure 1). It has been reported that during the expansion of the population, many insect species exhibit less genetic variation as a result of bottleneck and founder effects (Lindholm et al., 2005; Hawley et al., 2006). Less genetically variable populations can be considered as only a subset of the genetic diversity present in the native population, and furthermore, if populations are small, there must be a decreased genetic diversity (Roderick, 2004). However, from the present inter- and intra-population study and data analysis of C.eriosoma, it can be concluded that no genetic divergence exists among Indian populations. Further, C.eriosoma from other countries belongs to a different ancestral history and are homologous to Indian populations. The homogeneity observed across the populations of C.eriosoma indicates its poor ability to overcome the management hurdles and also shows its recent spread across the country. This simplifies the designing of both traditional and biotechnological management strategies. This is the first attempt to generate molecular data for this emerging pest from different parts of India. 


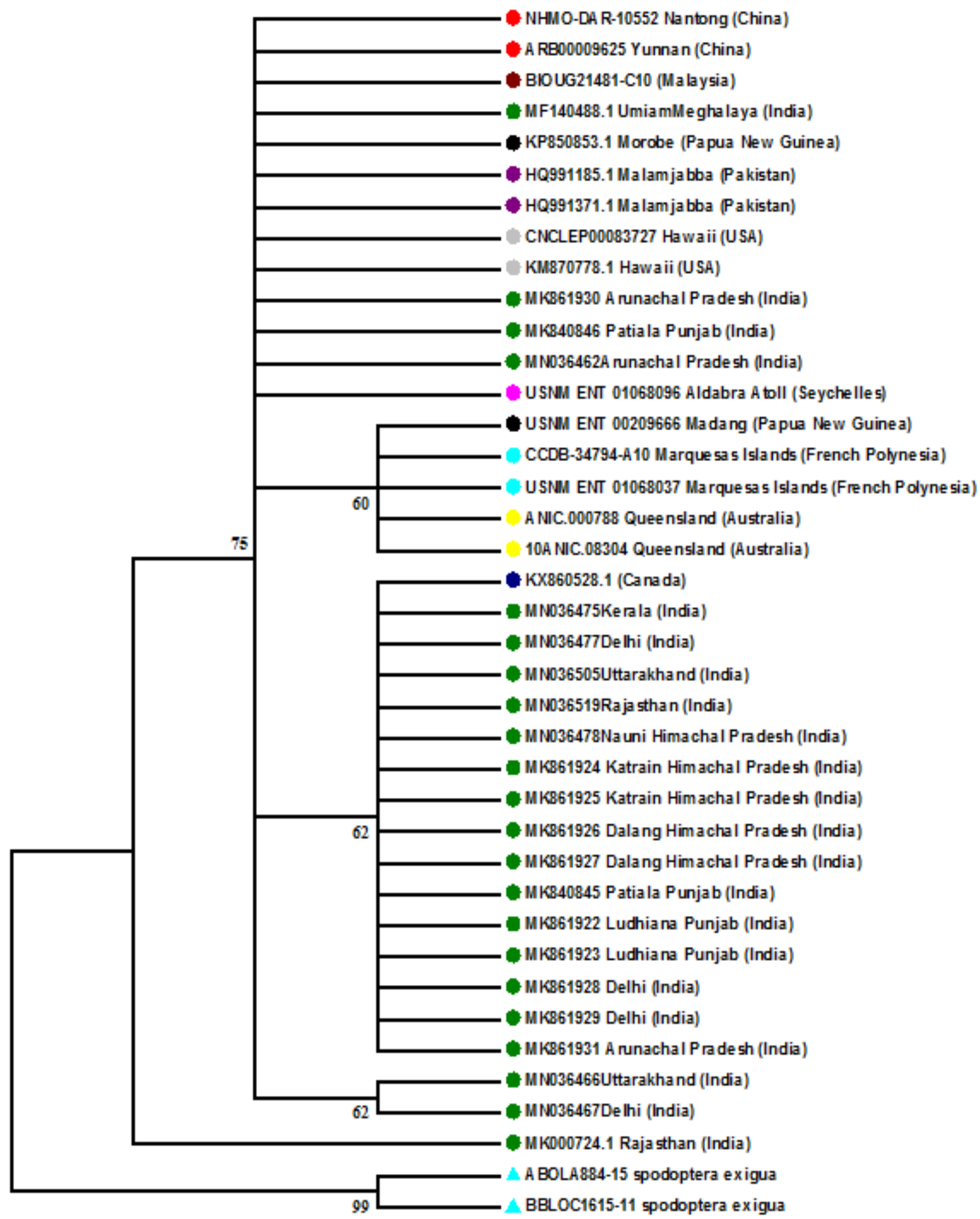

Figure 1 Maximum-likelihood (ML) phylogenetic consensus tree generated from the COI gene sequences of C.eriosoma. The consensus tree was inferred from 2000 bootstrap replicates. 


\section{Acknowledgments}

We are grateful to Head, Division of Entomology, Indian Agricultural Research Institute, Pusa Campus, New Delhi for providing the facilities to conduct the research work. We thank DST-SERB (SB/YS/LS-126/2014) for the financial assistance.

\section{Disclosure statement}

The authors declare that they have no competing interests.

\section{References}

Anonymous (1984) Annual report 1983. Mauritius Sugar Industry Research Institute, Reduit, Mauritius, Pp 77.

Broza M, Sneh B (1994) Bacillus thuringiensis spp. kurstaki as an effective control agent of lepidopteran pests in tomato fields in Israel. Journal of Economic Entomology 87:923-928.

Butani DK, Jotwani MG (1984) Insects in vegetables. Periodical Expert Book Agency, Delhi, India. Pp 356.

CABI (2007) Crop Protection Compendium. Wallingford, UK: CAB International. www.cabicompendium.org/cpc

Despres L, David JP, Gallet C (2007) The evolutionary ecology of insect resistance to plant chemicals. Trends in Ecology and Evolution (Amst) 22:298-307.

Dufay C (1970) Insects Lepidopteres Noctuidae Plusiinae. Fauna de Madagascar 31: 1-198.

EPPO (2004) Good plant protection practice, solanaceous crops under protected cultivation. EPPO Bulletin 34: 65-77.

Esper EJC (1789) Die Schmetterlinge in Abbildungen nach der Natur mit Beschreibungen. Theil IV: Die Eulenphalenen. Erlangen. W.Walthers. Pp.1-372.

Folmer O, Black M, Hoeh W, Lutz R, Vrijenhoek R (1994) DNA primers for amplification of mitochondrial cytochrome $\mathrm{c}$ oxidase subunit 1 from diverse metazoan invertebrates. Molecular Marine Biology and Biotechnology 3: 294-299.

Fu Y, Li W (1993) Statistical tests of neutrality of mutations Genetics 133:693-709.

Fu YX (1997) Statistical tests of neutrality of mutations against population growth, hitchhiking and background selection. Genetics 147:915-925.

Hawley DM, Hanley D, Dhondt AA, Lovette IJ (2006) Molecular evidence for a founder effect in invasive house finch (Carpodacus mexicanus) populations experiencing an emergent disease epidemic. Molecular Ecology 15:263-275
Hill DS (1983) Agricultural Insect Pests of the Tropics and Their Control. Cambridge University Press, Cambridge.

Librado P, Rozas J (2009) DnaSP V5: a software for comprehensive analysis of DNA polymorphism data. Bioinformatics 25:1451-1452.

Lindholm AK, Breden F, Alexander HJ, Chan WK, Thakurta SG, Brooks R (2005) Invasion success and genetic diversity of introduced populations of guppies Poecilia reticulata in Australia. Molecular Ecology 14:3671-3682.

Martin N, Workman P (1986) Greenlooper caterpillar control on greenhouse tomatoes with Bacillus thuringiensis. In Proceedings of the Thirty-Ninth New Zealand Weed and Pest Control Conference. Quality Inn, Palmerston North, August 12th to 14th, 1986. New Zealand Weed and Pest Control Society, Pp. 130-132.

Men UB, Thakre H S, Fulzele GR (1995) First record of six new insects associated with sunflower, Helianthus annuus Linn. in India. PKV Research Journal 19(1): 89.

Nair N, Shah B T, Debnath, Partha D, Dey B, Awasthi D P, Sujoy $H$ (2017) Insect pest complex of Pigeon pea (Cajanus cajan) in agroecosystem of Tripura, N.E. India. Journal of Entomology and Zoology Studies 5: 765-771

Prasad D, Singh KM, Katiyar RN (1983) Succession of insectpests in early maturing high yielding variety of pea, Pisum sativum Linn. Indian Journal of Entomology 45: 451-455.

Roderick GK (2004) Tracing the origin of pests and natural enemies: genetic and statistical approaches. In: Lester EE, Sforza R, Mateille T (Eds) Genetics, evolution and biological control. CABI, Cambridge, Pp 97-112.

Ronkay L, Ronkay G, Behounek G (2008) A Taxonomic Atlas of the Eurasian and North African Noctuoidea. Plusiinae I Witt Catalogue 1:1-348.

Ronkay L, Ronkay G, Behounek G (2010) A Taxonomic Atlas of the Eurasian and North African Noctuoidea. Plusiinae II Witt Catalogue 1: 1-280.

Saha NN, Saharia D (1983) Insects injurious to soybean in Assam. Journal of Research 4(2): 167-169.

Sharma G, Kumar R, Pathania PC (2008) Biodiversity of lepidopterous insects associated with vegetables in India - A study Indian Journal of Entomology $70: 4$.

Shashank PR, Longjam R (2014) Checklist of subfamily Plusiinae (Lepidoptera: Noctuidae) from India. Indian journal of Entomology 76(3): 229-240. 
Tajima F (1989) Statistical method for testing the neutral mutation hypothesis by DNA polymorphism. Genetics 123:585-595.

Tamura K, Glen S, Daniel P, Alan F, Sudhir K (2013) MEGA6: Molecular Evolutionary Genetics Analysis version 6.0. Molecular Biology and Evolution 30:2725-2729.

Taylor DE, Kunjeku E (1983) Development of an economic threshold for semi-loopers (Lepidoptera: Noctuidae) on soya-beans in Zimbabwe. Zimbabwe Journal of Agricultural Research 1: 89100.

Tripathi S R, Akhtar S (1986) Nutritive suitability of different food plants in Plusia eriosoma (Doubleday) (Noctuidae: Lepidoptera) Journal of Advanced Zoology 7( 2): 115-117.

Tripathi S R, Akhtar S (1988) Population dynamics of a cabbage noctuid Plusia eriosoma (Doubleday) (Lepidoptera) in response to certain ecological parameters. Annals of Entomology 6(1): 41-45.
Tripathi SR, Shari AK (1992) Fecundity table and intrinsic rate of natural increase in Plusia eriosoma (Doubleday) (Lepidoptera: Noctuidae). Indian Journal of Ecology 19(1):65-68.

Tripathi SR, Tripathi AK (1988) Development and growth of larva and pupa of Plusia eriosoma (Doubleday) (Lepidoptera: Noctuidae) in relation to larval diets. Journal of Advanced Zoology 9(1): 11-14.

Twinkle, Shashank PR, Chattopadhyay PC (2018) Taxonomy of agriculturally important plusiinae(Lepidoptera: Noctuidae). Indian Journal of Entomology 80(3): 748-760.

Walker F (1858) List of specimens of Lepidopterous insects in the collection of the British Museum 15: 1521-1888.

Zhang ZQ (Ed.) (2011) Animal Biodiversity: An Outline of Higher-level Classification and Survey of Taxonomic Richness (Addenda 2013). Zootaxa, 3703: 1-82. 